\title{
ANTIFUNGAL AND ANTIPATULIN ACTIVITY OF GLUCONOBACTER OXYDANS ISOLATED FROM APPLE SURFACE*
}

\author{
Martina BEVARDI ${ }^{1}$, Jadranka FRECE ${ }^{2}$, Dragana MESAREK ${ }^{2}$, Jasna BOŠNIR ${ }^{1}$, Jasna MRVČIĆ ${ }^{2}$, \\ Frane DELA $\check{S}^{2}$, and Ksenija MARKOV ${ }^{2}$ \\ Institute of Public Health "Dr. Andrija Štampar", Faculty of Food Technology and Biotechnology, University of \\ Zagreb², Zagreb, Croatia \\ Received in September 2012 \\ CrossChecked in 2012 \\ Accepted in March 2013
}

\begin{abstract}
Fungicides are the most common agents used in postharvest treatment of fruit and are the most effective against blue mould, primarily caused by Penicillium expansum. Alternatively, blue mould can be treated with antagonistic microorganisms naturally occurring on fruit, such as the bacterium Gluconobacter oxydans. The aim of this study was to establish the antifungal potential of the G. oxydans $1 \mathrm{~J}$ strain isolated from apple surface against Penicillium expansum in culture and apple juice and to compare it with the efficiency of a reference strain $G$. oxydans ATCC $621 \mathrm{H}$. The highest antifungal activity of $G$. oxydans $1 \mathrm{~J}$ was observed between days 3 and 9 with no colony growth, while on day 12, P. expansum colony diameter was reduced to $42.3 \%$ of the control diameter. Although $G$. oxydans $1 \mathrm{~J}$ did not fully inhibit mould growth, it showed a high level of efficiency and completely prevented patulin accumulation in apple juice.
\end{abstract}

KEY WORDS: antagonistic microorganisms, mould growth, Penicillium expansum, toxin accumulation

Due to the decay it leads to, blue mould can cause major losses in apple harvest, but its negative effects can be prevented by proper sanitation and efficient control. The most common cause of blue mould, the fungus Penicillium expansum causes fruit decay and stimulates the production of a carcinogenic mycotoxin patulin. Initially, patulin was used in pharmaceutics as an agent, but prolonged use in human trials has revealed that it causes gastrointestinal and dermal irritation, whereas animal models have showed that patulin is genotoxic but not carcinogenic (1). The

* The subject of this article has partly been presented at the International Symposium "Power of Fungi and Mycotoxins in Health and Disease" held in Primošten, Croatia, from 19 to 22 October 2011.
International Agency for Research on Cancer (IARC) has classified patulin as group 3 carcinogen to humans (2). The EU was among the first to set concentration limits for several mycotoxins, including patulin, to $50 \mu \mathrm{g} \mathrm{kg}^{-1}$ in fruit juices and fruit nectars, $25 \mu \mathrm{g} \mathrm{kg}^{-1}$ in solid apple products, and $10 \mu \mathrm{g} \mathrm{kg}^{-1}$ in apple-based products for infants and young children $(3,4)$. At high concentrations patulin may spoil the flavour of fruit intended for processing and its presence indicates that mouldy apples have been used in the production of juice. The most important and most common patulinproducing fungi belong to three genera of ascomycota: Penicillium, Aspergillus, and Byssochlamys, representing both commensal and pathogenic species found on the surface of apples (5). 
Apples have always been among the most frequently consumed fruit, and that is why the presence of patulin may present a serious health risk for humans and affect food processing industry (6). The most common agents used to treat patulin-contaminated fruit are fungicides $(7,8)$. However, their harmful effects on human health and the environment are well known (6), and their overuse increases the risk of resistance in treated microorganisms. These reasons have led to an intensive search for safer biological alternatives to control fruit and vegetable spoilage and potential toxin accumulation. One such alternative is the use of microorganisms naturally occurring on fruit and vegetable surfaces $(9,10)$, such as Gluconobacter oxydans.

The genus Gluconobacter includes five species used in food manufacturing primarily because it is harmless to human health. This genus belongs to a group of acetic acid bacteria (11) and has the ability to partially oxidise a number of carbohydrates and alcohols. Its species can grow in highly concentrated sugar solutions and at low $\mathrm{pH}$ values. Their growth behaviour and response to extreme culture conditions are remarkably unique (12).

The aim of this study was to isolate naturally present Gluconobacter oxydans from apple surface and to determine its effectiveness in controlling the growth and patulin production of Penicillium expansum.

\section{MATERIALS AND METHODS}

\section{Isolation and identification of the microbial culture}

G. oxydans was isolated from old varieties of five "Jonathan" cultivars collected aseptically and washed with sterile water. Aliquots $(0.1 \mathrm{~mL})$ of washing samples were spread on yeast-peptone-mannitol (YPM) plates (5.0 g of yeast extract, $3.0 \mathrm{~g}$ of peptone, and $25.0 \mathrm{~g}$ mannitol per litre) and potato dextrose agar (PDA) and incubated at $25{ }^{\circ} \mathrm{C}$ for 7 days. The colonies were chosen at random and identified according to their morphology, Gram staining, cell morphology, and catalase reaction. Samples were prepared and bacterial species identified using a Microflex LT $^{\mathrm{TM}}$ matrix-assisted laser desorption/ionisation time-oflight mass spectrometer (MALDI-TOF MS) following the procedure recommended by the manufacturer (Bruker Daltonik, Bremen, Germany). A colony of
YPM agar culture was suspended in $300 \mu \mathrm{L}$ water to obtain a homogeneous suspension of cells by vortexing for one minute. For the identification of species, the peaks from the generated mass spectra were compared with the reference spectra of the integrated database using the MALDI Biotyper Software package. All of the samples were analysed in triplicate and the final score was the mean value of three determinations.

\section{Culture preparation}

The G. oxydans strain, which is the usual contaminant of apples, capable of degrading patulin, was identical to the one held in the collection of microorganisms of the Zagreb University Faculty of Food Technology and Biotechnology (ZUFFTB) and recorded under serial no. $1 \mathrm{~J}$. The reference strain, $G$. oxydans ATCC $621 \mathrm{H}$, was obtained from Valio Ltd., Helsinki, Finland. G. oxydans ATCC $621 \mathrm{H}$ was maintained at $-70{ }^{\circ} \mathrm{C}$ on a medium with $\mathrm{Ca}\left(10 \mathrm{~g} \mathrm{~L}^{-1}\right.$ glucose, $1 \mathrm{~g} \mathrm{~L}^{-1}$ yeast extract, and $3 \mathrm{~g} \mathrm{~L}^{-1} \mathrm{CaCO}_{3}$ ) supplemented with $20 \%$ glycerol. Prior to inoculation, the cultures were transferred twice to YPM broth. The bacterial growth was determined after $72 \mathrm{~h}$ of incubation at $28^{\circ} \mathrm{C}$ by plate counting $\left(\mathrm{CFU} \mathrm{mL} \mathrm{mL}^{-1}\right)$.

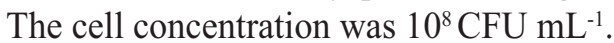

The Penicillium expansum strain 565 was obtained from the ZUFFTB collection of microorganisms. It was stored on slants of PDA ("Biolife", Milan, Italy) at $4{ }^{\circ} \mathrm{C}$. To obtain the inoculum, the mould was incubated on PDA slants at $25^{\circ} \mathrm{C}$ for 7 days and then added $2 \times 5 \mathrm{~mL}$ of sterile water solution of Triton X-100 (5 $\mathrm{mg} \mathrm{L}^{-1}$ ) (Sigma-Aldrich, St. Louis, MO, USA). The suspension was diluted to a concentration of $10^{6}$ spores $\mathrm{mL}^{-1}$.

Mould growth and patulin production were determined in two ways. Fungal colony growth was determined by measuring colony diameter $(\mathrm{mm})$ on YPM plates after inoculation with the reference strain G. oxydans ATCC $621 \mathrm{H}$ and with the isolated $G$. oxydans $1 \mathrm{~J}$ to compare their effects. Aliquots $(0.1 \mathrm{~mL})$

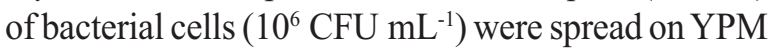
plates and after $2 \mathrm{~h}, 10 \mu \mathrm{L}$ of an aqueous suspension at the conidial concentration $\left(10^{4}\right.$ spores $\left.\mathrm{mL}^{-1}\right)$ of $P$. expansum 565 were added in the centre of each plate. Control samples did not contain $G$. oxydans. Radial colony growth was measured at three-day intervals over 15 days.

Patulin production by $P$. expansum was screened based on thin-layer chromatography (TLC) determinations from agar plugs cut from the central area of the colony. The plates were developed in the 
Table 1 Mould colony growth and the presence of patulin on YPM agar

\begin{tabular}{|c|c|c|c|c|c|c|}
\hline & \multicolumn{3}{|c|}{ Colony diameter / mm } & \multicolumn{3}{|c|}{ Patulin / agar plug } \\
\hline & & P. expansum & P. expansum & & P. expansum & P. expansum \\
\hline $\begin{array}{l}\text { Days after } \\
\text { inoculation }\end{array}$ & $\begin{array}{c}\text { P. expansum } \\
565\end{array}$ & $\begin{array}{c}565+ \\
\text { G. oxydans } \\
\text { ATCC } 621 \mathrm{H}\end{array}$ & $\begin{array}{c}565+ \\
\text { G. oxydans 1J }\end{array}$ & $\begin{array}{c}\text { P. expansum } \\
565\end{array}$ & $\begin{array}{c}565+ \\
\text { G. oxydans } \\
\text { ATCC } 621 H\end{array}$ & $\begin{array}{c}565+ \\
G . \\
\text { oxydans } 1 J\end{array}$ \\
\hline 3 & 20 & - & - & nd & nd & nd \\
\hline 6 & 34 & - & - & nd & nd & nd \\
\hline 9 & 44 & - & - & + & nd & nd \\
\hline 12 & 52 & 29.5 & 9 & + & nd & nd \\
\hline 15 & 58 & 33 & 21 & + & + & nd \\
\hline
\end{tabular}

nd-not detected

Table 2 Effect of Gluconobacter strains on fungal biomass and patulin concentration in apple juice.

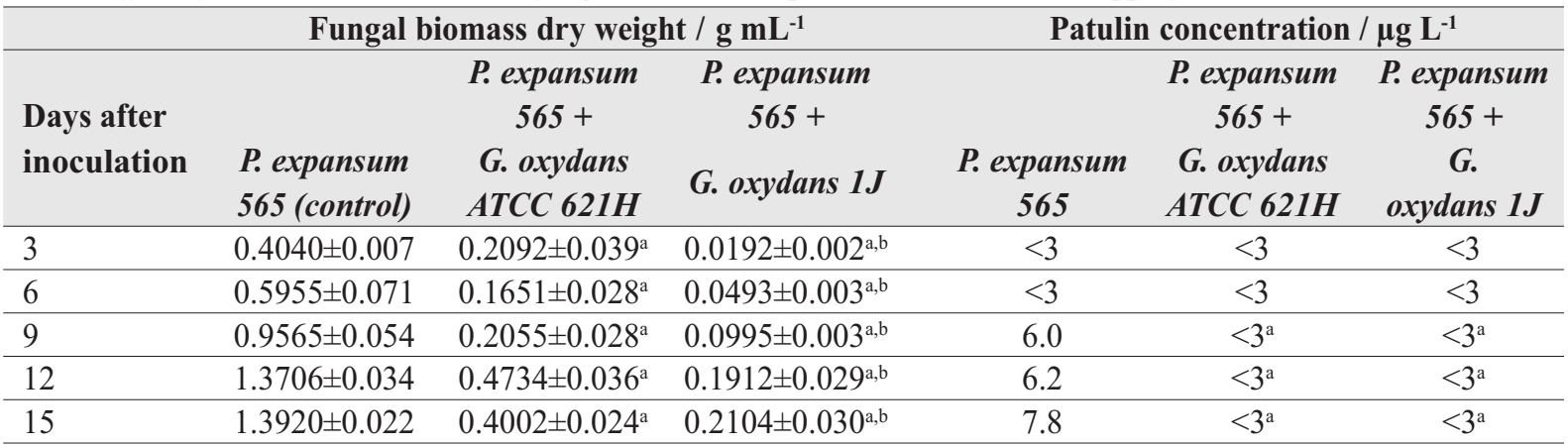

${ }^{a}$ Significantly different from control (Student's t-test; $\mathrm{P}<0.05$ ).

${ }^{b}$ Significantly different from the ATCC $621 \mathrm{H}$ strain (Student's t-test; $\mathrm{P}<0.05$ ).

Table 3 Comparison of $\mathrm{P}$. expansum mould biomass inhibition by the reference G. oxydans strain ATCC 621H and the natural, isolated strain $1 J$ in apple juice

\begin{tabular}{lccccc}
\hline \multirow{2}{*}{ Strain } & \multicolumn{5}{c}{ Inhibition / \% } \\
\cline { 2 - 6 } & Day 3 & Day 6 & Day 9 & Day 12 & Day 15 \\
\hline G. oxydans ATCC 621H & $48.22 \pm 2.23$ & $78.25 \pm 3.07$ & $78.52 \pm 2.74$ & $65.47 \pm 3.61$ & $71.25 \pm 3.55$ \\
\hline G. oxydans 1J & $95.25 \pm 2.91^{* *}$ & $91.73 \pm 3.13^{*}$ & $89.60 \pm 3.02^{*}$ & $86.05 \pm 2.73^{* *}$ & $85.89 \pm 3.38^{*}$ \\
\hline
\end{tabular}

*Significantly different from the reference ATCC $621 \mathrm{H}$ strain on days 6, 9, and 15 days (Student's $t$-test; $\mathrm{P}<0.05$ )

**Significantly different from the reference ATCC $621 \mathrm{H}$ strain on days 3 and 12 (Student's t-test; $\mathrm{P}<0.01$ )

solvent system containing toluene:ethyl acetate:formic acid (5:4:1) and after drying, patulin was detected as a fluorescent spot made visible by UV light $(\lambda=254 \mathrm{~nm})$ $(13,14)$. Rf values of the samples were compared with the Rf value of the patulin standard (Sigma- Aldrich, St. Louis, MO, USA) chromatographed simultaneously.

Alternatively, mould growth and patulin production were measured in clear apple juice (Maraska, Zadar, Croatia) over 15 days. Prior to the experiment, apple juice was screened for patulin. Each flask with $50 \mathrm{~mL}$ of apple juice was added $1 \mathrm{~mL}$ of spore suspension $\left(10^{6}\right.$ spores $\left.\mathrm{mL}^{-1}\right)$ alone or in combination with bacterial cells. The flasks were incubated in duplicate at $28^{\circ} \mathrm{C}$ for 15 days. The amount of mould biomass was determined gravimetrically by filtration through pre-weighed Whatman no. 1 filter paper. The filter paper and mycelia were dried in a hot-air oven at $105^{\circ} \mathrm{C}$ for $24 \mathrm{~h}$ and mycelia weight obtained by reweighing the filter paper with dried mycelia. Patulin was determined using a Shimadzu HPLC equipped with a UV detector (Shimadzu, Kyoto, Japan). No preparation was required for the clear apple juice. Patulin was eluted with water:acetonitril:perchloric acid (95:5:0.095) and separated on a 5- $\mu \mathrm{m} \mathrm{C}_{18}$ chromatographic column $(150 \mathrm{~mm} \times 4.6 \mathrm{~mm})$ at a flow rate of $1.0 \mathrm{~mL} \mathrm{~min}^{-1}$. The UV detector wavelength was set at $276 \mathrm{~nm}$ and sample injection volume at $50 \mu \mathrm{L}$. Total run time was $10 \mathrm{~min}$. The detection limit for patulin was $1 \mu \mathrm{g} \mathrm{kg}^{-1}$ and quantification limit $3 \mu \mathrm{g} \mathrm{kg}^{-1}$. 


\section{Statistical analysis}

We used the statistical package Statistica v. 6.1 (SAS Institute, Cary, NC, USA) to compare the activities of the two G. oxydans strains in apple juice (but not in agar). The differences in mould biomass and patulin concentrations in apple juice were tested with Student's $t$-test. The differences were considered significant if the $P$-value was less than 0.05 .

\section{RESULTS AND DISCUSSION}

\section{Culture findings}

G. oxydans strain $1 \mathrm{~J}$ identified in our study had the following characteristics: negative Gram stain reaction, ellipsoidal to rod-shaped cells, single or in pairs and rarely in chains, and positive catalase test. The identity of the bacterial species was confirmed by the MALDI-TOF MS. Both the $1 \mathrm{~J}$ and the reference ATCC $621 \mathrm{H}$ strains were highly inhibitory to $P$. expansum 565 growth, especially over the first 12 days (Table 1). Patulin in agar plugs cut from pure fungal dish cultures was first detected after 9 days. Rapid colony diameter growth for the reference strain was observed between days 12 and 15. Patulin production started from day 9 through day 15 . The strain $1 \mathrm{~J}$ significantly reduced the mould growth of the $P$. expansum 565 and completely inhibited patulin production.

\section{Apple juice}

Table 2 shows the effects of both $G$. oxydans strains on the growth of $P$. expansum and patulin accumulation in apple juice over 15 days. The highest increase in mould biomass growth $\left(1.392 \mathrm{~g} \mathrm{~mL}^{-1}\right)$ was recorded on day 15. Patulin accumulation started 9 days after inoculation, and reached maximum concentration on day $15\left(7.8 \mu \mathrm{g} \mathrm{L}^{-1}\right)$. Both strains significantly inhibited the growth of mould biomass over the 15 postinoculation days compared to control $(P<0.05)$, but the $1 \mathrm{~J}$ strain was significantly more efficient $(P<0.05)$. No significant differences between the strains were found in degrading patulin, as both reduced it to below the detection limit of $3 \mu \mathrm{g} \mathrm{L}^{-1}$. These findings are in accordance with Ricelli et al. (6), who observed that incubation with G. oxydans degraded patulin in apple juices up to $96 \%$. Ricelli et al. (6) also reported that natural microflora from apples, such as the bacterium
G. oxydans, is capable of degrading patulin to a less toxic compound called ascladiol. G. oxydans ATCC $621 \mathrm{H}$ showed partial (48\%) inhibition of mould growth in apple juice at the beginning of incubation and increased inhibition (65\% to $78 \%)$ from day 6 to day 15 .

In turn, the inhibition of mould growth with the isolate $1 \mathrm{~J}$ was about $92 \%$ to $95 \%$ over the first six days of inoculation. From days 12 to 15 this inhibition weakened a little to $85 \%$ and $86 \%$, respectively, but remained significantly greater than with the ATCC $621 \mathrm{H}$ strain (Table 3).

It is difficult to control apple decay caused by Penicillium by biological means due to the high competitiveness of this pathogen $(9,15,16)$. Some authors have shown that the best antagonist against fungi that cause fruit decay is the very microflora from their surfaces (17-19). Our results confirm that microflora naturally occurring on fruit surfaces could provide effective protection against fungal growth and patulin accumulation. This is a preliminary study, and our results will be validated using apples infected with P. expansum. Future studies should include other biocontrolling agents which naturally occur as fruit micoflora, such as yeasts (20-22), and investigate their effectiveness against mould growth and patulin.

\section{REFERENCES}

1. Puel O, Galtier P, Oswald IP. Biosynthesis and toxicological effects of patulin. Toxins 2010;2:613-31. doi: 10.3390/ toxins 2040613

2. International Agency for Research on Cancer (IARC). Overall Evaluation of Carcinogenicity. An updating of IARC monographs volumes 1 to 42 . IARC monographs on the evaluation of carcinogenic risks to humans Supplement 7. Lyon: IARC; 1987.

3. Codex Committee on Food Additives and Contaminants (CODEX). Maximum level for patulin in apple juice and apple juice ingredients and other beverages. Codex Stan 235-2003.

4. EUROPEAN UNION. Commission Regulation no. 1881/2006 setting maximum levels for certain contaminants in foodstuffs. Off J Eur Commun 2006;L364:5-24.

5. Baert K, Devlieghere F, Flyps H, Oosterlinck M, Ahmed MM, Rajković A, Verlinden B, Nicolaï B, Debevere J, De Meulenaer B. Influence of storage conditions of apples on growth and patulin production by Penicillium expansum. Int J Food Microbiol 2007;119:170-81.

6. Ricelli A, Baruzzi F, Solfrizzo M, Morea M, Fanizzi FP. Biotransformation of Patulin by Gluconobacter oxydans. Appl Environ Microbiol 2007;73:785-92. doi: 10.1128/ AEM.02032-06 
7. Bandoh S, Takeuchi M, Ohsawa K, Ohsawac K, Higashiharaa $\mathrm{K}$, Kawamotoa Y, Gotoa T. Patulin distribution in decayed apple its reduction. Int Biodeter Biodegrad 2009;63:379-82. doi: 10.1016/j.ibiod.2008.10.010

8. Conway WS, Janisiewicz WJ, Leverentz B, Saftner RA, Camp MJ. Control of blue mold of apple by combining controlled atmosphere, an antagonist mixture, and sodium bicarbonate. Postharvest Biol Technol 2007;45:326-32. doi:10.1016/j.postharvbio.2007.03.005

9. Janisiewicz WJ, Korsten L. Biological control of postharvest diseases of fruits. Annu Rev Phytopathol 2002;40:411-41. doi: 10.1146/annurev.phyto.40.120401.130158

10. Reddy KRN, Farhana NI, Salleh B, Oliviera CAF. Microbiological control of mycotoxins: present status and future concerns. In: Méndez-Vilas A, editor. Current research, technology and education topics in applied microbiology and microbial biotechnology. Badajoz: FORMATEX; 2010. p. 1078-86.

11. Tanasupawat $\mathrm{S}$, Thawai C, Yukphan $\mathrm{P}$, Moonmangmee D, Itoh T, Adachi O, Yamada Y. Gluconobacter thailandicus sp. nov., an acetic acid bacterium in the a-Proteobacteria. J Gen Appl Microbiol 2004;50:159-67.

12. Deppenmeier U, Hoffmeister M, Prust C. Biochemistry and biotechnological applications of Gluconobacter strains. Appl Microbiol Biotechnol 2002;60:233-42. doi: 10.1007/s00253-002-1114-5

13. Samson RA, Hoekstra ES, Frisvad JC. Introduction to Food and Airborne Fungi. $7^{\text {th }}$ ed. Utrecht: Centraalbureau voor Schimmelcultures; 2004.

14. Scott PM. Mycotoxin analysis by TLC. In: Touchstone JC, editor. Advances in thin layer chromatography. New York (NY): John Willy and sons Inc.; 1982. p. 321-42.

15. Kourkoutas Y, Kanellaki M, Koutinas AA. Apple pieces as immobilization support of various microorganisms. LWT-
Food Sci Technol 2006;39:980-6. doi: 10.1016/j. lwt.2006.02.024

16. Scherm B, Ortu G, Muzzu A, Budroni M, Arras G, Migheli Q. Biocontrol activity of antagonistic yeasts against Penicillium expansum on apple. J Plant Pathol 2003;85:20513. doi: $10.4454 / j p p . v 85 i 3.1032$

17. Janisiewicz WJ, Tworkoski TJ, Kurtzman CP. Biocontrol potential of Metschnikowia pulcherrima strains against blue mould of apple. Phytopathology 2001;91:1098-108. doi: 10.1094/PHYTO.2001.91.11.1098

18. Zhang D, Spadaro D, Garibaldi A, et al. Selection and evaluation of new antagonists for their efficacy against postharvest brown rot of peaches. Postharvest Biol Technol 2010;55:174-81. doi: 10.1016/j.postharvbio.2009.09.007,

19. Kurzman CP, Droby S. Metschnikowia fructicola, a new ascosporic yeast with potential for biocontrol of postharvest fruit rots. Syst Appl Microbiol 2001;24:395-9.

20. Spadaro D, Ciavorella A, Dianpeng Z, Garibaldi A, Gullino ML. Effect of culture media and $\mathrm{pH}$ on the biomass production and biocontrol efficacy of a Metschnikowia pulcherrima strain to be used as a biofungicide for postharvest disease control. Can J Microbiol 2010;56:128-37. doi: 10.1139/w09-117

21. Reddy KRN, Spadaro D, Gullino ML, Garibaldi A. Potential of two Metschnikowia pulcherrima (yeast) strains for in vitro biodegradation of patulin. J Food Prot 2011;74:154-6. doi: 10.4315/0362-028X.JFP-10-331

22. Leverentz B, Conway WS, Janisiewicz W, Abadias M, Kurtzman CP, Camp MJ. Biocontrol of the food-borne pathogens Listeria monocytogenes and Salmonella enterica serovar poona on fresh-cut apples with naturally occurring bacterial and yeast antagonists. Appl Environ Microbiol 2006;72:1135-40. doi: 10.1128/AEM.72.2.11351140.2006 


\section{Sažetak}

ANTIFUNGALNA I ANTIPATULINSKA AKTIVNOST GLUCONOBACTER OXYDANS IZOLIRANE S POVRŠINE JABUKE

Tretiranje voća fungicidima, nakon berbe, uobičajeni je način suzbijanja plave plijesni. Međutim, propadanje voća može se spriječiti i upotrebom antagonističkih mikroorganizama, kao što je bakterija Gluconobacter oxydans. Svrha ovoga rada bila je izolirati prirodnu mikrobnu populaciju s površine jabuka i istražiti moguće inhibitorno djelovanje Gluconobacter oxydans 1J na plavu plijesan, Penicillium expansum, najvažnijeg uzročnika kvarenja jabuka u skladištu. Najveća antifungalna aktivnost bakterije primijećena je između 3. i 9. dana, kada nije zabilježen porast kolonija, a nakon 12. dana promjer kolonije plijesni bio je manji za 42,3 \%. Iako istraživana bakterija Gluconobacter oxydans $1 \mathrm{~J}$ nije u potpunosti inhibirala rast plijesni u jabučnom soku pokazala je visoku razinu učinkovitosti (od $86 \%$ do $95 \%$ ). Gluconobacter oxydans $1 \mathrm{~J}$ djelomično inhibira rast plijesni i u potpunosti biosintezu patulina, ovisno o vremenu i uvjetima uzgoja.

KLJUČNE RIJEČI: antagonistički mikroorganizmi, nakupljanje toksina, Penicillium expansum, rast plijesni

\section{CORRESPONDING AUTHOR:}

\section{Ksenija Markov}

Faculty of Food Technology and Biotechnology,

University of Zagreb

Pierottijeva 6, 10000 Zagreb, Croatia

E-mail:kmarko@pbf.hr 